\title{
Adult sons and daughters of alcoholics
}

\begin{abstract}
Summary
Children of alcoholics comprise $25-50 \%$ of the general population in Russia and, by adulthood, the self-esteem of these children of alcoholics (VDA) is seriously undermined by misconceptions learned in childhood from their parents. This paper illustrates some of these learned messages: "I can do nothing properly; I cannot think properly; I cannot trust anyone except myself; I should not feel or express my feelings." The author's psychotherapeutic responses are provided, with specific exercises that have been found useful.
\end{abstract}

Conclusion: Children of alcoholics in need of psychotherapy to correct traumatic beliefs of their childhood and restore healthy self-esteem. Practice has shown high effectiveness of such psychotherapy.
Volume 5 Issue 2 - 2018

\author{
MoskalenkoVD \\ Scientific and Practical Center of Narcology, Russia
}

Correspondence: Moskalenko VD, Professor, System family psychotherapist, Scientific and Practical Center of Narcology, Moscow, Russia, Email valentinajoy@mail.ru

Received: February 01, 2018 | Published: March 02, 2018

\section{Prevalence of children of parents with alcoholism}

The exact number of children living in families with one or two alcohol-dependent parents is unknown, but reportedly substantial. According to some authors every fifth or sixth schoolchild, ${ }^{1,2}$ identifies him or herself as a child of alcoholic parents. When studying the self-reports of a large contingent of adult Americans 18 years and older $(\mathrm{N}=42,862)$, more than $50 \%$ had a positive family history of alcoholism. ${ }^{3}$ It is difficult to determine the prevalence of parental alcoholism in Russia because it has not been studied. In the United States, from 28 to 34 million children under the age of 18 are children of alcoholics. ${ }^{3}$ One in four schoolchildren reports the abuse of alcohol by the parent. ${ }^{1,2}$ One of three families reports that one of its members currently abuses alcohol. ${ }^{4}$ According to an elementary schoolteacher who reported to our clinic (the National Scientific Center of Narcology of the Ministry of Health of the Russian Federation), five to six children in classes of 26-28, are children of alcoholics. Her information matches research data showing a prevalence of $1: 4 .^{5}$

\section{Presenting complaints of children of alcoholics \\ In my clinical experience, these children, as adults, come to the clinic with the following complaints}

"I do not have a relationship with the opposite sex". "I had two husbands - the first alcoholic, he died drunk driving, the second husband did not drink or smoke, but I divorced him. I do not know why, he was too correct. We can now talk in a friendly way. I live in a civil marriage with an alcoholic musician. I'm not satisfied with this relationship, but I'm happier and lighter with it. I want to understand why I'm attracted to alcoholics."

"I'm 38 years old, I want to get married, I do not know how to get along with men. I really loved a man, he turned out to be a drug addict. And he left me. I'm ready to crawl on my knees all around Moscow Ring Road, if only he would come back to me ". These are all problems of close relationships brought about, in my opinion, by difficult childhoods, long periods of suffering, a lack of skills in acknowledging and expressing feelings, problems of low self-esteem, exaggerated self-criticism, and perfectionism. This is usually combined with admirable personal qualities, dedication, high efficiency, great achievements in creative or other chosen fields, generosity, and altruism.

\section{Negative self-beliefs}

These patients have learned four main negative messages from their alcoholic parents
a. I cannot do anything right.
b. I cannot think correctly.
c. I cannot trust anyone except myself.
d. I should not feel or express my feelings.
e. I cannot do anything right.

This painful and unfair view comes from that childhood, when parents sent only reproaches, negative feedbacks to the child. How many times did Natasha try to make her dad happy, happy! But in this she did not succeed. How did Kolya try to please his parents! But he was criticized and criticized, even mocked, sometimes his parents looked at him as if he were misunderstanding something. If alcoholism has settled in the house, then criticism, accusation and condemnation live there.

Antonina at the age of 5 wanted to please my mother with wellwashed cups, but during washing she broke one cup. Since then, in her memory sits like a poisonous arrow: "Your hands do not grow from there, from other people!" Andrew tells how he at the age of 7 tried to collect a collapsed toy truck. Then my father came up and said what Andrei has been remembering for 20 years now: "Do you have anything you can do as it should be?" After several years of life in such a family atmosphere, the child becomes intimidated, cautious, refuses to take risks, and is afraid to move forward. It seems that he is to blame for everything. And in the center of the belief "I cannot do anything right", his self-respect dies, he is covered by the dust of his ability. 
After living in such a family atmosphere, the child becomes intimidated, cautious, refuses to take risks, and is afraid to move forward. He or she feels to blame for everything: "I cannot do anything right." Self-respect dies.

\section{Therapuetic exercise}

I have found the following exercise to be helpful: Draw a picture or write a few lines that illustrate a memory from childhood where "I cannot do anything right." Discuss this picture or text with a person you trust. What did you feel when you heard it for the first time and repeatedly? What do you feel now about this? How would you respond to this today? What would you, as an adult, say to that injured child now? As a loving parent of that child? If there is no person with whom you can discuss these issues, do so by writing in a diary. Make a commitment to appreciate your strengths.

\section{I cannot think right}

What does this belief inspire? When a child sees one, and he is told that he should see something different, it confuses him, confusing him. The child learns not to trust his thinking. Everything in his mind is twisted, sometimes put upside down. "My father works so hard. Sometimes he needs to relax, do you understand this? "This is also promoted by the words often pronounced to the child" Do you know what you are saying? "Ignoring alcoholism interferes with clear thinking.

"When I was a girl, no one said that our mother drinks too much. Pope was silent, brothers were silent. What happens in the house was not discussed. Probably everyone thought that the problem would disappear if everyone behaved as if everything was going well. The conspiracy of silence continued all the time while I lived in the family.

Recognize the reality of pain. Thinking about the problem is straightforward, calling things by their proper names is like betrayal, and betrayal gives a sense of guilt. It's more reliable to pretend than to protest. In an alcohol family, a sense of self-preservation nurtures the conviction "I cannot think right".

Same format - examples, event/response, exercise

\section{An exercise}

Draw a picture or write a few lines that illustrate your belief "I cannot think right".

\section{I cannot trust anyone except myself}

Adult people can trust others if their basic physical and emotional needs are met in their childhood. Confidence is absorbed by the child when the environment is secure and people are honest with him. These conditions are often absent in the alcohol family. If a child comes across a family with abusive treatment, if the behavior of parents is unpredictable, he learns not to trust. Such a child always wakes, always on the alert and expects the worst. He can suspect everyone. $\mathrm{He}$ is not satisfied with the most important human need - the need for security. Dissatisfaction in safety remains in adulthood. Many children with alcoholism were afraid to invite friends. Others in the house often talked about a possible fire if the dad falls asleep drunk with a cigarette. In the family there could be beatings of children, their insults with words. Sexual abuse also happens in such families. Fear hung in the air of the hearth and ruled everyday life.

\section{An exercise}

Draw a picture or write in words a paragraph illustrating the belief in your mind "I cannot trust anyone but myself."

\section{I should not feel or express my feelings}

"In our family, we never talked about feelings. Even when my sister died, and my mother cried a lot. I wanted to help her, but I did not know how to talk about my feelings, about her feelings. And my father continued to drink and shout at my mother. I was sorry for my father. But I could not say anything". "When I was in second grade, I had a dog. One evening her father let her go. I always kept her on a leash, because we lived near the road. The dog ran away and got under the car. I cried, I was angry. My father looked at me contemptuously, shouted and said that if I really want to cry, he will give me such that I will cry for a long time. He was so big and so rude to me. Since then, I think that my feelings are not important to anyone. “

\section{An exercise}

Draw a picture or write a few words as an illustration to your presentation coming from childhood "I should not feel or express my feelings."

\section{Behavioral adaptation}

The above four ideas about themselves gave rise to numerous obligations. For example, a child could believe that he should remain silent, be "quieter than water, below the grass." Or the child was told that he should be strong, always look happy, should not discuss household chores with someone outside the house. Every child wants to be loved. Therefore, each child performed these "must" or "should not". "When they love me, the child believed, peace and security will reign in our home. Then they will consider me a valuable person. "

\section{Discussion}

Thus, our practical experience of working with adult children with alcoholism of parents shows that these children have learned from childhood "poisonous messages" that throughout life violate self-esteem, self-esteem. Often, such personality traits prevent them from building a partnership that satisfies them. Sons and daughters need psycho-corrective work. Experience of such work is given in the article. Many of them noted significant improvements in their attitude towards themselves and other people. Children with alcoholism need psychotherapy to correct the traumatic beliefs of their childhood and restore healthy self-esteem. Practice has shown the high effectiveness of such psychotherapy.

\section{The child's behavior was adapted to make him feel loved}

Realized that criticizing an uncle-alcoholic means betraying a family. Now, 38-year-old Elena, recalls the nightmare in which she lived from infancy to 12 years. My uncle lived in the same entrance, his wife left him. Uncle all came and came to their house, although he was already forcibly expelled from the threshold. His father fought 
with him, even grabbed a knife. He threatened to call the police, but he never called. Lena thought what would happen if a drunken uncle came into the house when she was alone at home. Mom about this Lena did not say anything. The girl felt that around the drunkenness of his uncle a conspiracy of silence was formed. During the fight, everyone in the house shouted, and then pretended that nothing serious had happened. Lena pretended that she was all right, often smiling. Despite her bewilderment at what was happening, she guessed that it was better not to ask anyone about it. About a uncle, not a word. "I do not know," Elena says now, "as I guessed that if I want to be loved, I should not talk about the behavior of my uncle." The theme of alcoholism in the family was taboo, a topic that cannot be touched.

\section{An exercise}

Remember what you did in childhood to win love in the family. To be loved, I should.

a. Elena: to maintain a conspiracy of silence.

b. You: To be loved, I felt that I should not

c. Elena: be yourself.

d. You:

\section{An exercise}

Draw or write a few words about what you did to win love, at the age of 6, 12 and 17 years.

a. Elena: Age 6 years: draws a face with a sealed mouth ("I was silent").

b. You:

c. Age 12 years: Finally, my uncle moved to another place, he got along with another woman who also often drinks. And although I knew that my uncle would not come as suddenly as it was before, I was still afraid to invite my friends. As if the shadow of my uncle was floating in the air. Then I decided not to remember it, to erase it from memory. To be loved in the family, I decided to ignore everything that we previously had to do with a drunken uncle.

\section{d. You:}

e. Age 17: Elena says that at 17 she was still ashamed of "what was." I became very shy. I did not know why I was so out-ofhome. Only now I understand, it seemed to me, they would pay attention to me so much and love me.

\section{f. You:}

\section{Reprogramming}

Just as a computer works on the program inserted into it, a person also has a program built into his mind and subconscious. What you read in the above chapters is the life program. Unfortunately, the program is stable and works in a similar way even under changed conditions. Age has changed, and the reactions are the same as they were in adolescence. The husband can be already the second, another person, but the quality of life is the same as in the first marriage. This is the firmness of the program. Otherwise, this phenomenon can be called a family scenario. Change the program, make adjustments to the family scenario is difficult, but, I believe you can. Even if this is a small change, improving the quality of life can be overwhelming. That's where "a little bit" means so much.

\section{Exercise "we form new ideas about ourselves"}

Concentrate on your breathing. You breathe peace, universal harmony. You breathe in love. Just hold your breath, imagine that you are saturated with love. Relax. If you still feel some discomfort, do not be upset. Respectfully refer to discomfort, but know that this is a temporary condition. Soon you will feel pleasant relaxation and pacification. Unpleasant, painful feelings may appear at the beginning of the path to healing. Trust your feelings. Appreciate them, what they are. Analyze the above four ideas about yourself, which have been imprinted since childhood. Look at these ideas from the point of view of an adult intelligent person who understands that alcoholism is a disease.

Look at them from the point of view of an adult who also understands that every "I cannot" means only "I will not." The difference between these two statements is vital to you. All that in childhood was your "I cannot do it" now, in adulthood, it became angry, you ran away from the eyes of mom and dad. Otherwise, you would "hit the nuts". Now, in adulthood, you can decide whether to recognize your anger or not to recognize whether it is possible to express it and how to do it in the most appropriate way in a certain setting. If you say to yourself "I will not", it means "I do not choose". You can achieve the coveted state "I will", stepping over the stage "I will not". Forget your "I cannot". Go to the destination station "I will." Write new ideas about yourself, taking into account the knowledge that alcoholism is a disease, and you are a person worthy of love and already loved. New ideas about yourself can look like this. I can think and recognize all my feelings, but I do not betray anyone. In an alcoholic house there is a disease, not a devil or an evil spirit. I can talk about my feelings and still be loved. I can be that person who I am, and yet be loved.

If you feel uncomfortable, uncomfortable with this exercise, but this is a perfectly legitimate feeling. Let it not bother you and does not stop the exercise. Continue to rewrite your beliefs, complete the exercise. Restructuring beliefs will free you from the burden of past experience and from fear. Reaching positive statements about yourself like I am a worthy person. I accept life calmly and strive to understand myself and others. Loudly you can say aloud I can feel any feelings. Feelings do not last forever, they pass or change. I, not my feelings are responsible for my thoughts and behavior. Treat yourself with a gentle, gentle patience. Positive energy will replace the unpleasant feelings, and hope will replace despair.

\section{Acknowledgments}

I am grateful to my patients and clients for trusting my inner life and sharing my pain. I always remain grateful to my teachers in the field of psychiatry, narcology, psychotherapy.

\section{Conflict of interest}

None.

\section{References}

1. Jennison KM, Johnson KA. Parental alcoholism as a risk factor for DSM-IV-defined alcohol abuse and dependence in American women: 
The protective benefits of dyadic cohesion in marital communication Am J Drug Alcohol Abuse. 2001;27(2):349-374.

2. Morey CK. Children of alcoholics: A school based comparative study. $J$ Drug Educ.1999;29(1):63-75.

3. Russel M, Henderson C, Blume SB. Children of alcoholics: a review of the literature. New York, USA: Children of Alcoholics Fndn Inc; 1985.
4. Goodwin DW. Is alcoholism hereditary? 2nd ed. New York: Ballantine Books; 1988. $260 \mathrm{p}$

5. Hall CW, Webster RE. Traumatic symptomatology characteristics of adult children of alcoholics. J Drug Educ. 2002;32(3):195-211. 